\title{
KARAKTERISTIK PENGERINGAN BIJI PALA (Myristica fragranshoutt) MENGGUNAKAN ALAT PENGERING HYBRID DENGAN SUMBER PANAS DARI ENERGI SURYA DAN SERBUK KAYU \\ (Drying Characteristics of Nutmeg Seed (Myristica Fragranshoutt) by Using a Hybrid Dryer Used Heat Sources from Solar and Sawdust Energy)
}

\author{
Debi Sarnadi ${ }^{1}$,Raida Agustina ${ }^{1}$, Rita Khathir ${ }^{1}$ * \\ ${ }^{1}$ Program Studi Teknik Pertanian, Fakultas Pertanian, Universitas Syiah Kuala \\ *Corresponding author: rkhathir@ unsyiah.ac.id
}

\begin{abstract}
Abstrak. Manfaat dari proses pengeringan pala yaitu untuk tujuan pengawetan. Tujuan penelitian ini adalah untuk mengkaji proses pengeringan biji pala menggunakan alat pengering hybrid dengan sumber energi matahari dan biomassa serbuk kayu. Total biji pala yang dikeringkan adalah $15 \mathrm{~kg}$. Pembakaran serbuk kayu dilakukan selama pengeringan di malam hari dengan laju $3 \mathrm{~kg} / \mathrm{jam}$. Parameter penelitian meliputi iradiasi surya, temperatur, kelembaban relatif, kadar air, dan uji organoleptik terhadap warna dan aroma. Hasil penelitian menunjukkan bahwa iradiasi rata-rata yang diperoleh adalah $131,61 \mathrm{~W} / \mathrm{m}^{2}$ pada hari pertama dan dihari kedua 131,08 $\mathrm{W} / \mathrm{m}^{2}$. Temperatur dalam ruang pengering $\left(44^{\circ} \mathrm{C}\right)$ lebih tinggi dibandingkan dengan temperatur lingkungan $\left(33,5^{\circ} \mathrm{C}\right)$. Kelembaban relatif rata-rata ruang pengering $(27,7 \%)$ lebih rendah dari kelembaban relatif rata-rata di lingkungan $(42,7 \%)$. Untuk mencapai kadar air biji pala $10 \%$ dibutuhkan waktu 32 jam secara kontinu dengan alat pengering dan 39 jam selama 4 hari secara intermitten dengan metode penjemuran. Kapasitas alat pengering $2 \mathrm{x}$ lebih besar dari kapasitas penjemuran, dan biji pala kering menggunakan alat pengering lebih disukai oleh panelis dari segi warna dan aromanya.
\end{abstract}

Kata kunci :Pengering Hybrid, Pengeringan Pala

\begin{abstract}
The benefit of drying process of nutmeg seed is to prolong its life. The objective of the study was to observe the drying method of nutmeg seed by using a hybrid dryer used the heat sources from solar and biomass (sawdust) energy. The total nutmeg seed used in this study was approximately $15 \mathrm{~kg}$. The combustion rate of biomass during the night was $3 \mathrm{~kg} / \mathrm{h}$. The parameters investigated were solar irradiation, temperature, relative humidity, moisture content and organoleptic test on color and flavor. The results showed that the average solar irradiation was $131.61 \mathrm{~W} / \mathrm{m}^{2}$ on the first and second day drying. The average temperature in the drying chamber $\left(44^{\circ} \mathrm{C}\right)$ was higher than the average ambient temperature $\left(33.5^{\circ} \mathrm{C}\right)$. The average relative humidity in the drying chamber $(27.7 \%)$ was lower than the average ambient relative humidity $(42.7 \%)$. To have the final moisture of nutmeg seed $10 \%$, the drying time needed was 32 hours continuously by using hybrid dryer and 39 hours for 4 days intermittent by sundrying method. The dryer capacity was double of sundrying capacity, and the color and flavor of dried nutmeg seed produced by using hybrid dryer was preferred by respondents.
\end{abstract}

Keywords: Hybrid Dryer, Drying Nutmeg Seeds

\section{PENDAHULUAN}

Pala adalah salah satu produk unggul dari Aceh. Pertanian pala di Provinsi Aceh masih banyak terkonsentrasi di wilayah Kabupaten Aceh Selatan dengan luas areal 15 ribu hektar, sedangkan di Aceh Barat Daya total luas lahan pala 4.102 hektar yang terdiri dari tanaman yang sudah menghasilkan sekitar 1.669 hektar, sedangkan selebihnya belum menghasilkanmencapai 165 ha dengan produksi sebesar 418 ton per tahun. Produksi pala di wilayah Aceh rata-rata 500-600 kg per hektar per tahun (BPJS, 2015)

Berdasarkan data di atas dapat diprediksi jumlah produksi pala di Aceh dari tanaman yang sudah menghasilkan dengan luas 1.669 hektar adalah sebesar 834,5 ton dan jumlah biji pala adalah 108,485 ton per tahun. Pengeringan di tingkat petani bijipala yang selama ini dilakukan hanya dengan cara penjemuran langsung di bawah sinar matahari dengan menggunakan terpal. Pengeringan dengan metode ini mempunyai kelemahan yaitu memerlukan tempat yang luas, waktu pengeringan yang lama, tidak higienis dan mudah 
terkontaminasi oleh serangga dan faktor lingkungan lainnya.Hal ini yang menyebabkan terjadinya penurunan mutu pada biji pala kering.Pengeringan menggunakan alat pengering hybrid diharapkan bisa mengatasi permasalahan menurunnya mutu pala sehingga dapat meningkatkan mutu pala, menekan kehilangan hasil atau susut hasil pala, memudahkan dalam pengangkutan hasil pala dan meningkatkan nilai tambah hasil pala yang dampaknya dapat meningkatkan pendapatan petani.

\section{MATERI DAN ETODELOGI PENELITIAN}

\section{Waktu dan Tempat Penelitian}

Penelitian ini dilakukan di Kebun Percobaan Fakultas Pertanian, Laboratorium Analisis Pangan Program Studi Teknologi Hasil Pertanian dan Laboratorium Teknik Pasca Panen Program Studi Teknik Pertanian Universitas Syiah Kuala pada bulan Juli 2017 Desember 2017

\section{Alat dan Bahan}

Adapun alat yang digunakan pada penelitian ini adalah alat pengering, terpal, oven, desikator,blower,timbangan digital, termometer infra red, termometer alkohol, solarimeter, humidity meter dan anemometer. Bahan yang digunakan adalah biji pala yang telah dikupas fulinya dan serbuk kayu. Adapun bentuk dari alat pengering hybrid dapat dilihat di gambar 1.

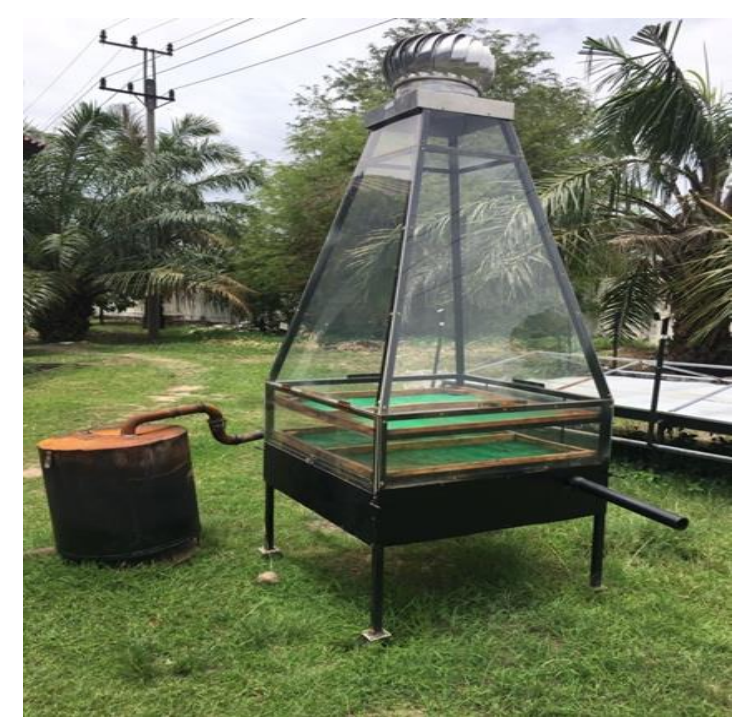

Gambar 1. Alat Pengering Hybrid

\section{Prosedur Penelitian}

Adapun prosedur penelitian ini adalah sebagai berikut :

a) Tahap pertama adalah persiapan alat pengering. Alat pengeringan hybrid diletakkan dilapangan terbuka yang tidak terkena naungan sepanjang hari. Posisi alat membujur Utara Selatan sehingga lintasan matahari bergerak dari sisi satu ke sisi lain dari alat pengering.

b) Tahapan kedua adalah persiapan biji pala.Biji pala diambil dari kebun petani di Desa Trieng Meuduroe Tunong, Kecamatan Sawang, Kabupaten Aceh Selatan. Buah pala 
dikupas untuk memisahkan antara biji pala dan fuli atau bunga pala dengan menggunakan pisau. Kemudian dilakukan pengukuran kadar air awal biji pala.

c) Tahapan ketiga adalah proses pengeringan dan pengambilan data. Proses pengeringan dilakukan secara kontinu, dimana pada siang hari memanfaatkan energi matahari dan pada malam hari menggunakan energi pembakaran serbuk kayu (biomassa). Selama proses pengeringan dilakukan pengamatan kondisi iradiasi matahari, temperatur dan kelembaban relatif di dalam alat pengeringan dan di lingkungan, kecepatan aliran udara, dan kadar air akhir. Pengeringan dengan metode penjemuran dilakukan di atas plastic terhadap $5 \mathrm{~kg}$ biji pala dan pengeringan dengan alat dilakukan terhadap $10 \mathrm{~kg}$ biji pala. Proses pengeringan dilakukan sampai kadar air biji pala mencapai $10 \%$.

\section{Parameter Penelitian}

\section{a. Iradiasi}

Iradiasi surya diukur dengan alat solarimeter dalam satuan Watt $/ \mathrm{m}^{2}$. Pengukuran iradiasi surya dilakukan dengan persamaan berikut :

$$
\mathrm{R}=\frac{\text { Data Hasil Pengukuran }(\mathrm{mV})}{\text { Faktor Kalibrasi }\left(\mathrm{mV} / \mathrm{kW} / \mathrm{m}^{2}\right)} \times 1000
$$

Faktor kalibrasi $=17,2 \mathrm{mV} / \mathrm{KW} / \mathrm{m}^{2}$

\section{b. Temperatur}

Pengukuran temperatur dilakukan selama proses pengeringan dalam interval waktu 60 menit. Titik pengamatan temperatur meliputi temperatur lingkungan, temperature rak 1 , temperature rak 2 , temperature tungku/ruang pembakaran, temperatur rcerobong dan temperature pipa penukar panas. Pengamatan temperatur dilakukan dengan thermometer alcohol dan thermometer infrared.

\section{c. Kelembaban Relatif (RH)}

Pengukuran dilakukan dengan interval waktu selang 60 menit selama proses pengeringan. Alat yang digunakan adalah humidity meter merek CHINO dengan seri HN-K buatan Jepang. Posisi pengukuran RH yaitu di ruang pengering, meliputi Rak 1, dan Rak 2 dan di lingkungan.

\section{g.Kadar Air}

Analisis kadar air dilakukan dengan menggunakan metode oven.Kadar air basis basah dapat ditentukan dengan Persamaan 2.

$$
\begin{aligned}
K A_{b b}= & \frac{m 1-m 2}{m 1} \times 100 \% \\
& \text { Dimana : } \\
& \mathrm{KA}_{\mathrm{bb}}=\text { kadar air basis basah }(\%) \\
& \mathrm{m} 1=\text { berat awal bahan }(\mathrm{g}) \\
& \mathrm{m} 2=\text { berat kering bahan }(\mathrm{g})
\end{aligned}
$$

\section{f. Organoleptik}

Panelis menilai warna dan aroma pada berbagai sampel bahan, sesuai dengan instruksi yang telah tertera pada form penilaian uji organoleptik. Pengujian menggunakan uji hedonik berdasarkan kriteria sangat tidak suka sampai sangat suka dalam bentuk angka1-5. Skor yang diberikan terdiri dari 1 (sangat tidak suka), 2 (tidak suka), 3 (netral), 4 (suka) dan 5 (sangat suka). Penilaian diwakili oleh 30 panelis dari berbagai kalangan.

\subsection{Analisis Data}

Data pengamatan yang diperoleh dianalisis secara deskriptif. Hasil analisis data tersebut ditampilkan dalam bentuk grafik dan tabel, dengan menggunakan parameter nilai rata-rata, nilai maksimum dan nilai minimum. 


\section{HASIL DAN PEMBAHASAN}

\section{Proses Pengeringan}

Pengeringan biji pala pada penelitian ini menggunakan dua metode yaitu pengeringan dengan metode penjemuran alami dan menggunakan alat pengering surya hybrid. Pengeringan dengan metode alami ialah pengeringan dengan cara menjemur biji pala dengan sinar matahari secara langsung, dimana metode ini dimulai dari pagi (pukul 08.00 WIB) hingga sore hari (pukul 18.00 WIB). Pengeringan pala dengan metode penjemuran di atas terpal plastik membutuhkan waktu selama 4 hari ( 39 jam).

Proses pengeringan dengan menggunakan alat pengering hybrid dimulai pada tanggal 13 November 2017 dan berakhir pada 14 November 2017 (32 jam). Pada penelitian ini biomassa yang digunakan berupa serbuk gergaji. Proses pembakarannya saat pertama kali tungku dihidupkan biomassa yang digunakan sebanyak $3 \mathrm{~kg}$, dan setiap satu jam biomassa di tambah sebanyak $3 \mathrm{~kg}$, total biomassa yang digunakan adalah sebanyak $39 \mathrm{~kg}$ selama $13 \mathrm{jam}$. Kadar air awal biji pala basah adalah $82 \%$. Sedangkan kadar air akhir yang diinginkan adalah $10 \%$.

\section{Iradiasi Surya}

Data pengukuran iradiasi surya selama proses pengeringan yaitu selama 4 hari dapat dilihat pada Gambar 2.

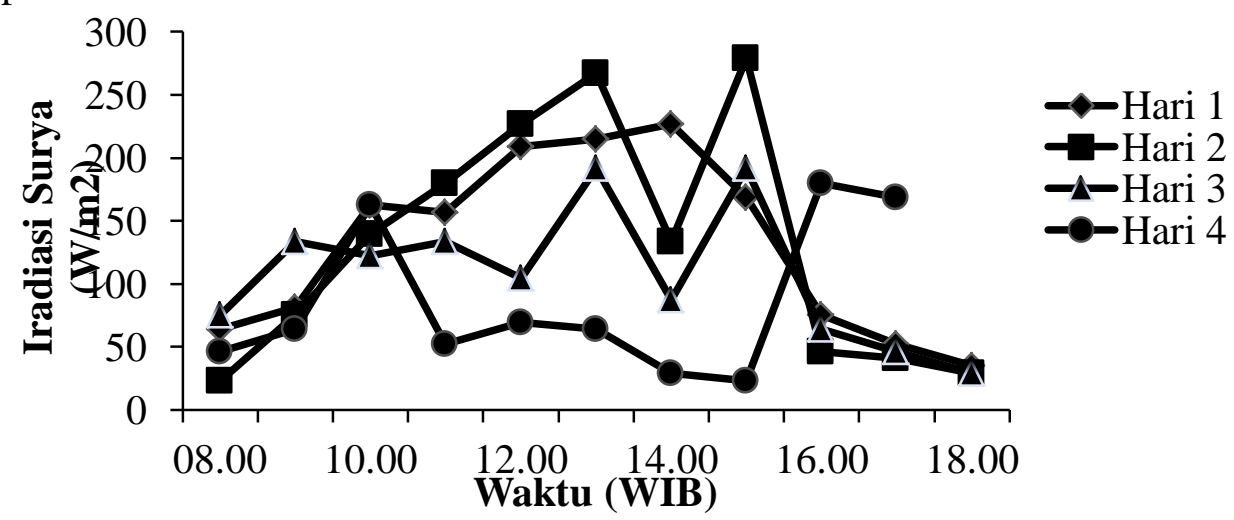

Gambar 2. Iradiasi suryaselama 4 hari penjemuran

Berdasarkan Gambar 2, dapat dilihat bahwa nilai iradiasi surya pada hari 1 berkisar antara 34,88-226,74 W/m ${ }^{2}$ dengan rata-rata iradiasi surya sebesar $131,61 \mathrm{~W} / \mathrm{m}^{2}$, dimana iradiasi surya tertinggi terdapat pada pukul $13.00 \mathrm{WIB}$ sebesar $226,74 \mathrm{~W} / \mathrm{m}^{2}$ dan iradiasi surya terendah terdapat pada pukul $18.00 \mathrm{WIB}$ sebesar $34,88 \mathrm{~W} / \mathrm{m}^{2}$. Iradiasi surya pada hari 2 berkisar antara 23,26-279,07W/m ${ }^{2}$ dengan rata-rata iradiasi surya sebesar $131,08 \mathrm{~W} / \mathrm{m}^{2}$, dimana iradiasi surya tertinggi terdapat pada pukul $15.00 \mathrm{WIB}$ sebesar $279,07 \mathrm{~W} / \mathrm{m}^{2}$ dan iradiasi surya terendah terdapat pada pukul $08.00 \mathrm{WIB}$ sebesar $23,26 \mathrm{~W} / \mathrm{m}^{2}$. Iradiasi surya pada hari 3 berkisar antara 29,07-191,86W/m² dengan rata-rata iradiasi surya sebesar 107,29 $\mathrm{W} / \mathrm{m}^{2}$, dimana iradiasi surya tertinggi terdapat pada pukul 13.00 dan $15.00 \mathrm{WIB}$ sebesar $191,86 \mathrm{~W} / \mathrm{m}^{2}$ serta iradiasi surya terendah terdapat pada pukul $18.00 \mathrm{WIB}$ sebesar 29,07 $\mathrm{W} / \mathrm{m}^{2}$. Iradiasi surya pada hari 4 berkisar antara 23,26-168,60 W/m dengan rata-rata iradiasi surya sebesar $86,05 \mathrm{~W} / \mathrm{m}^{2}$, dimana iradiasi surya tertinggi terdapat pada pukul $17.00 \mathrm{WIB}$ sebesar $168,60 \mathrm{~W} / \mathrm{m}^{2}$ dan iradiasi surya terendah terdapat pada pukul 15.00 WIB sebesar $23,26 \mathrm{~W} / \mathrm{m}^{2}$. 
Nilai iradiasi surya tertinggi terdapat pada hari ke-1 dan iradiasi surya terendah terdapat pada hari ke-4. Selama pengeringan dengan menggunakan alat pengering hybrid dan penjemuran dengan sinar matahari langsung menunjukkan bahwa rata-rata iradiasi surya terendah terdapat pada pukul 08.00 WIB dan pukul 18.00 WIB, hal ini disebabkan karena pada pukul tersebut jumlah iradiasi surya yang dipancarkan oleh matahari tidak terlalu banyak.

Iradiasi surya berfluktuasi sepanjang waktu karena dipengaruhi oleh posisi matahari dan kecerahan langit. Kondisi maksimum iradiasi surya dicapai pada cuaca baik dengan langit cerah yang memungkinkan radiasi surya yang dipancarkan dapat diserap lebih banyak ke bumi. Berdasarkan pengamatan pada penelitiajn ini, potensi iradiasi surya yang bagus untuk pengeringan terjadi pada pukul 10.00 WIB sampai dengan 12.00 WIB.

\section{TemperaturSelama Proses Pengeringan}

Hasil pengukuran temperatur penjemuran selama proses pengeringan dapat dilihat pada Gambar 3.

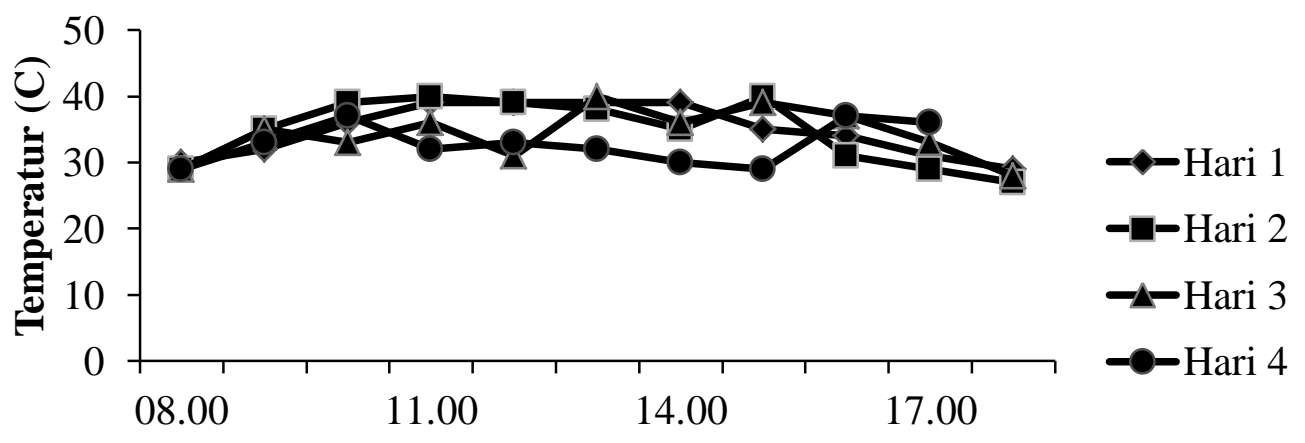

Waktu (WIB)

Gambar 3. Temperatur penjemuran selama 4 hari

Berdasarkan Gambar 3 dapat dilihat bahwa temperatur tertinggi yang dicapai adalah 37 ${ }^{\circ} \mathrm{C}$. Temperatur penjemuran selama pengeringan pada hari ke-1 berkisar antara $29-37^{\circ} \mathrm{C}$ dengan temperatur rata-rata $34,82^{\circ} \mathrm{C}$. Temperatur penjemuran selama pengeringan pada hari ke-2, ke-3, dan ke-4 berkisar antara $27-37^{\circ} \mathrm{C}$ dengan temperatur rata-rata $33,63^{\circ} \mathrm{C}, 33,81^{\circ} \mathrm{C}$ dan $32,9^{\circ} \mathrm{C}$. Temperatur penjemuran hari ke-4 lebih rendah karena radiasi surya yang tersedia pada hari itu juga lebih rendah.

Terdapat 5 titik temperatur yang diukur yaitu temperatur rak 1 , temperatur rak 2, temperatur ruang pembakaran, temperatur cerobong dan temperatur pipa penukar panas. Hasil pengukuran temperatur penjemuran dapat dilihat pada Gambar 4. 


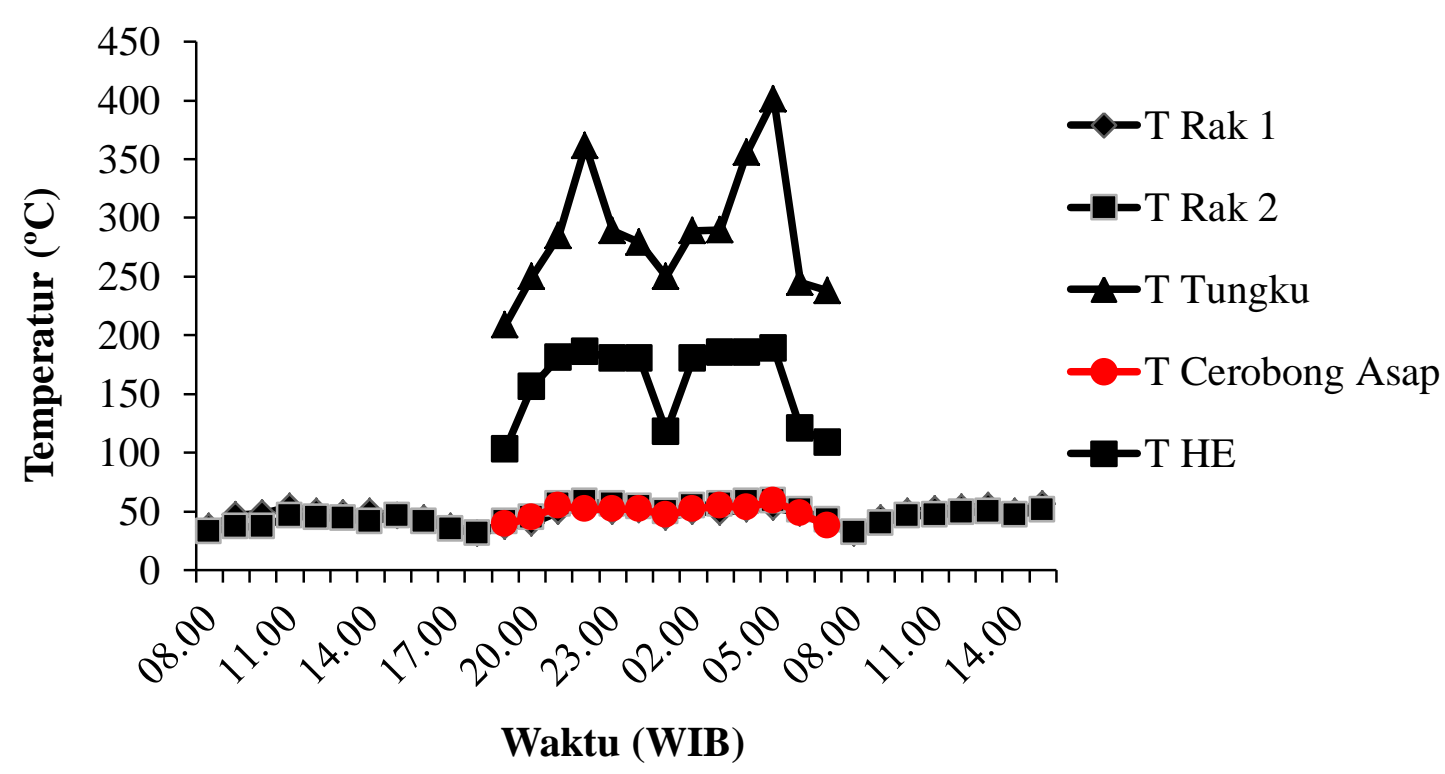

Gambar 4. Temperatur ruang Pengering Hybrid

Berdasarkan Gambar 4, dapat dilihat bahwa terjadi perubahan temperatur setiap jamnya. Trend perubahan temperatur dapat dianalisis dalam 3 fase, yaitu pengeringan sumber energi matahari hari ke-1, pengeringan malam hari dengan sumber energi biomassa, dan pengeringan dengan sumber energi matahari hari ke-2.Hasil penelitian menunjukkan, dimana terdapat perbedaan temperatur pengeringan, antara pala yang dikeringkan dengan metode pengeringan secara langsung menggunakan terpal dan pala yang dikeringkan dengan alat pengering, dimana temperatur didalam ruang pengering lebih tinggi dibandingkan dengan temperatur pada media terpal. Temperatur tertinggi terjadi pukul 10.00 WIB sampai dengan pukul 15.00 WIB, hal ini sesuai dengan pernyataan Kartasapoetra (2004) dalam Putri (2012) selama siang hari sampai dengan pukul \pm 15.00 WIB lebih banyak energi yang diradiasikan matahari.

Pada saat siang hari temperatur pada rak 1 lebih tinggi dari rak 2 dikarenakan rak 1 berada di atas dan terkena cahaya matahari secara langsung, sedangkan pada malam hari temperatur lebih tinggi pada rak 2, dikarenakan rak 2 berada di atas tungku pembakaran. Secara rata-rata dapat dilihat bahwa temperatur dalam ruang pengering lebih tinggi dari temperatur lingkungan. Hal ini menunjukkan bahwa alat pengering hybrid mampu menaikkan temperatur pengeringan, baik pada siang hari maupun pada malam hari, sehingga proses pengeringan menjadi lebih singkat.

\section{Kelembaban Relatif (RH)}

Kelembaban udara pengering (RH) sangat berperan penting dalam proses pengeringan karena kelembaban udara menunjukkan kandungan uap air yang ada di udara. Semakin tinggi kandungan uap air dalam uadara, akan semakin memperlambat proses pengeringan. Hasil pengukuran RH lingkungan dapat dilihat pada Gambar 5. 


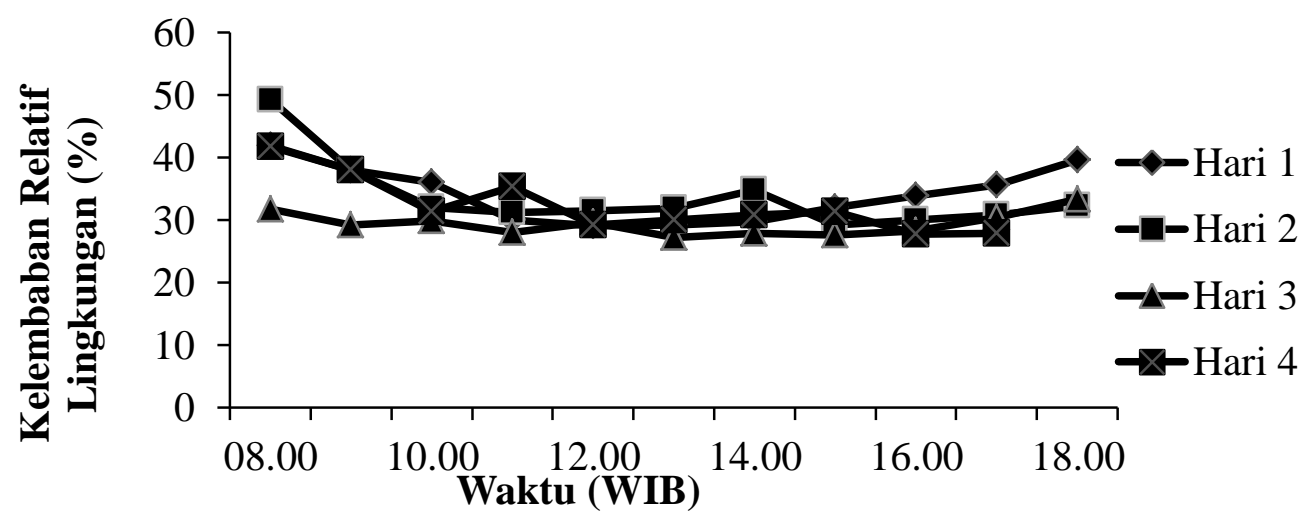

Gambar 5. Kelembaban relatif pengeringan metode penjemuran

Berdasarkan Gambar 5, dapat dilihat bahwa pada hari ke 1 RH tertinggi adalah sebesar $41,9 \%$ pukul 08.00 WIB dan terendah $29,1 \%$ pukul 12.00 WIB, RH rata-ratanya adalah 34,16\%. Pada hari ke 2 RH tertinggi adalah 49,3\% pukul 08.00 WIB dan terendah 29,3\% pukul 15.00 WIB, RH rata-ratanya dalah 33,77\%. Hari ke $3 \mathrm{RH}$ tertinggi adalah sebesar $33,4 \%$ pukul 18.00 WIB dan terendah $27,3 \%$ pukul 13.00 WIB, RH rata-ratanya adalah $29,43 \%$. Selanjutnya pada hari ke 4 RH tertingginya adalah $41,8 \%$ pukul 08.00 WIB dan terendah $27,8 \%$ pukul $16.00 \mathrm{WIB}$, RH rata-ratanya adalah sebesar 32,40\%. Rata-rata $\mathrm{RH}$ tertinggi hasil pengukuran selama 4 hari terdapat pada hari ke 1.Pengukuran dihentikan pada hari ke 4 pukul 18.00 WIB. Hasil pengukuran kelembaban relatif ruang pengering hybrid dapat dilihat pada Gambar 6.

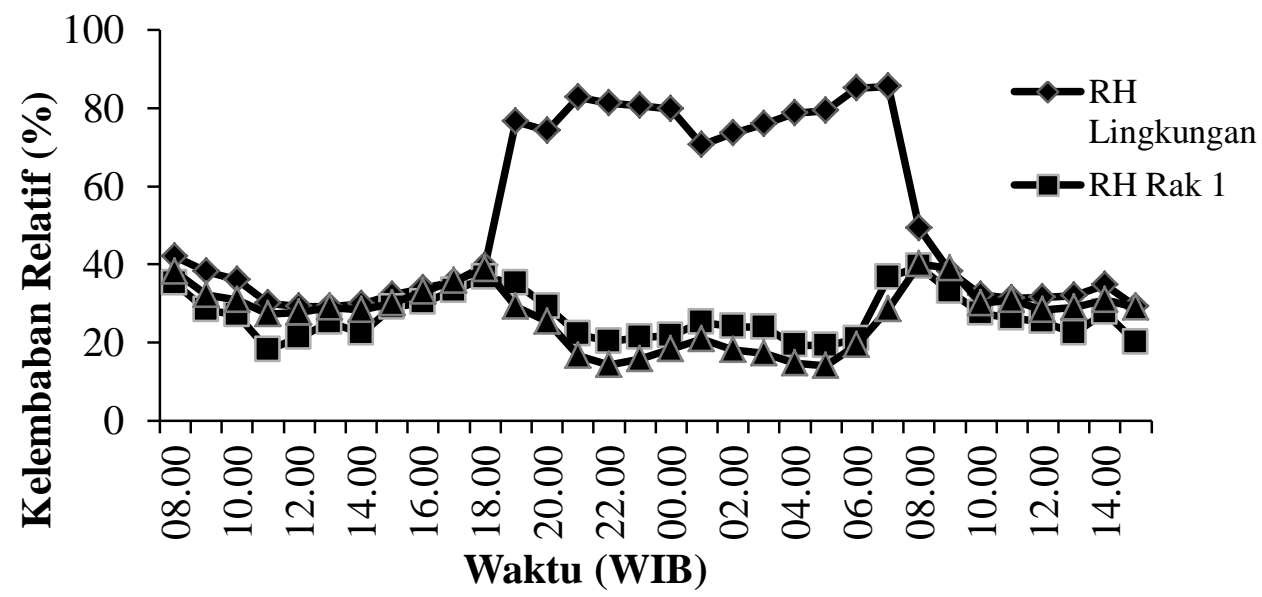

Gambar 6. Kelembaban relatif ruang pengering

Berdasarkan gambar 6 dapat dilihat perbandingan antara $\mathrm{RH}$ lingkungan dengan $\mathrm{RH}$ ruang pengering, dimana $\mathrm{RH}$ lingkungan lebih tinggi dari pada $\mathrm{RH}$ ruang pengering. Sama halnya dengan hasil pengamatan pada temperatur yang menunjukkan bahwa temperatur ruang pengering lebih tinggi dibandingkan temperatur lingkungan. Fluktuasi RH yang terjadi selama proses pengeringan sama dengan temperatur.

Terjadi fluktuasi RH setiap jamnya, dimana RH lingkungan saat malam hari sangat tinggi bila dibandingkan dengan siang hari,berbeda halnya dengan alat pengering hybrid, $\mathrm{RH}$ didalam ruang pengering saat malam hari cukup rendah dikarenakan temperatur didalam ruang pengering hybrid yang tinggi. Hal ini membuktikan alat pengering hybrid cocok untuk 
pengeringan, disamping alat pengering hybrid bisa meningkatkan suhu pengeringan, alat pengering hybrid juga bisa menekan RH menjadi lebih rendah.

\section{Penurunan Kadar air}

Hasil perhitungan kadar air selama pengeringan dengan sinar matahari langsung dapat dilihat pada Gambar 7.

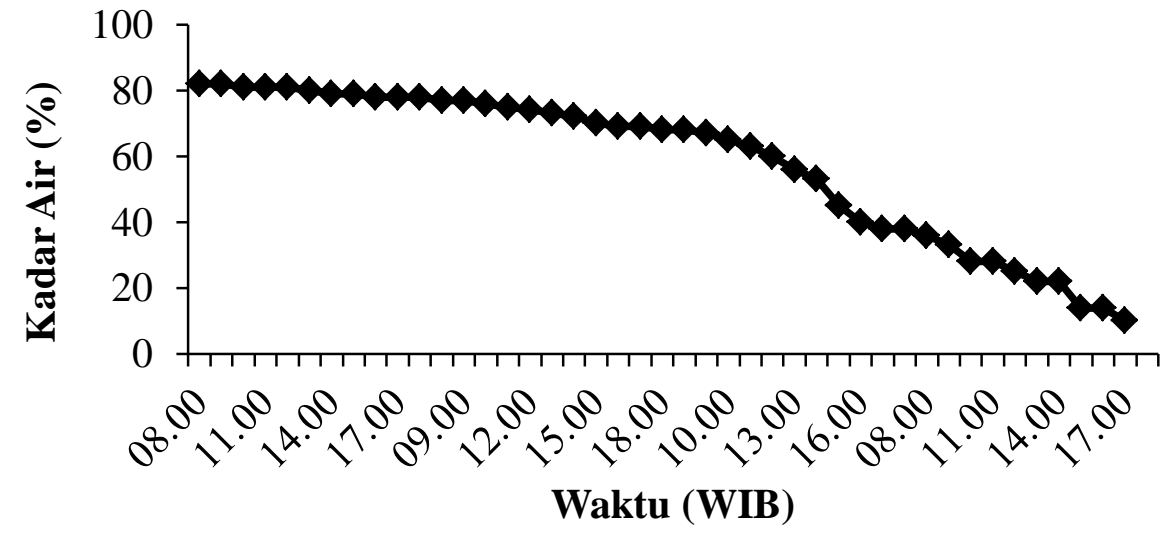

Gambar 7. Kadar air pala selama pengeringan metode penjemuran

Berdasarkan Gambar 7, dapat dilihat bahwa penurunan kadar air yang curam atau besar terdapat pada hari ke 3 dan hari ke 4 . Pada hari ke 4 kadar air pala sudah mencapai $36 \%$ pukul 08.00 WIB. Pala mencapai kadar air akhir maksimal yang diinginkan yaitu $10 \%$ pada hari ke 4 pukul 17.00 WIB. Hal ini berbeda dengan pernyataan Kakomole (2012) bahwa penurunan kadar air lebih besar pada awal proses pengeringan dan kemudian menurun seiring dengan berjalannya proses pengeringan karena kandungan air bebas yang sudah berkurang.

Pala yang dikeringkan dengan metode penjemuran secara langsung diatas terpal membutuhkan waktu yang lebih lama untuk mencapai kadar air 10\% yakni $39 \mathrm{jam} / 4$ hari (intermiten) dikarenakan proses pengeringan yang sangat bergantung kepada sinar matahari untuk energi pengeringan, dimalam hari dimana matahari tidak tersedia, pengeringan dihentikan untuk kemudian dilanjutkan kembali dihari berikutnya sampai bahan mencapai kadar air 10\%. Kendala ini membuat pengeringan dengan metode penjemuran secara langsung tidak efektif dan memakan banyak waktu. Hasil pengukuran kadar air pala dengan menggunakan alat pengering dapat dilihat di gambar8.

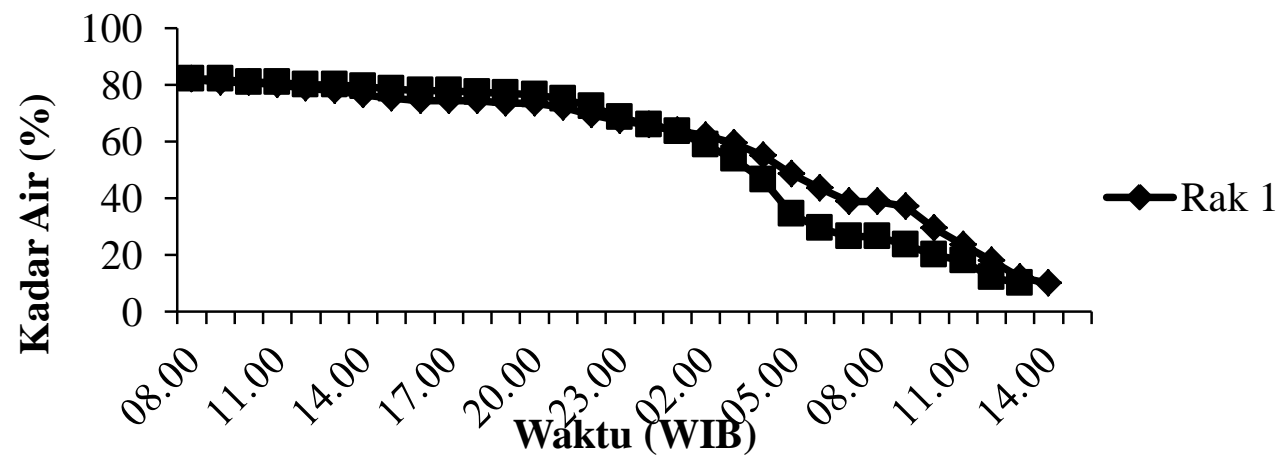

Gambar 8. Kadar air pala alat pengering hybrid

Berdasarkan Gambar 13, dapat dilihat proses penurunan kadar air selama pengeringan menggunakan alat pengering hybrid. Kadar air awal biji pala adalah $82 \%$. Pola grafik penurunan kadar air sangat menyerupai pola grafik penurunan berat. Pada hari ke-1, 
penurunan kadar air biji pala di rak 1 lebih besar dari pada penurunan kadar air biji pala di rak 2. Namun pada hari ke-2, prosesnya menjadi terbalik. Pada pukul 07.00 WIB di hari berikutnya kadar air biji pala di rak 1 berkisar 38-40\%. Sedangkan pada rak 2 saat pukul 07.00 WIB kadar air terendah yaitu sebesar 25-28\%. Penurunan kadar air pada rak 2 lebih cepat dibandingkan rak 1 yang dikarenakan posisi rak 2 yang berada di atas tungku pembakaran.

Hasil pengeringan pala tercepat terdapat pada rak 2 yaitu pada hari 2 pukul 12.00 WIB pala sudah mencapai kadar air maksimalnya sebesar $10 \%$ dengan temperatur rak pengering sebesar $49^{\circ} \mathrm{C}$, temperatur lingkungan $37^{\circ} \mathrm{C}$ dan kelembaban relatif (RH) $28,3 \%$. Hasil pengeringan tercepat pada rak 2 ini memiliki temperatur rata-rata ruang pengering sebesar $45,25^{\circ} \mathrm{C}$. Temperatur rata-rata alat pengering ini masih memenuhi kisaran syarat temperatur yang dibutuhkan untuk proses pengeringan biji pala yaitu antara $40^{\circ} \mathrm{C}$ sampai $65^{\circ} \mathrm{C}$.

Pengeringan dengan menggunakan alat pengering hybrid memiliki beberapa keuntungan dibandingkan pengeringan dengan metode tradisonal, diantaranya bahan yang akan dikeringkan jadi lebih cepat kering dibandingkan dengan pengeringan tradisional. Selanjutnya bahan terbebas dari kontaminasi lingkungan, yang membuat kualitas bahan yang dikeringan menjadi lebih bagus, keuntungan selanjutnya pengeringan yang bisa dilakukan secara terus menerus tanpa jeda waktu karena alat pengering hybrid tidak hanya menggunakan energi surya sebagai sumber energi pengeringan, tapi juga menggunakan energi biomassa sebagi sumber energi ke-2. Energi biomassa hanya di pakai ketika malam hari dan pada saat cuaca lagi mendung dimana energi matahari tidak tersedia.

\section{Hasil Pengujian Organoleptik Warna dan Aroma Biji Pala}

Hasil pengujian organoleptik pala sebanyak 3 sampel yang diuji oleh 30 orang panelis dapat dilihat pada Tabel 1.

Tabel 1. Hasil Uji Organoleptik Pala

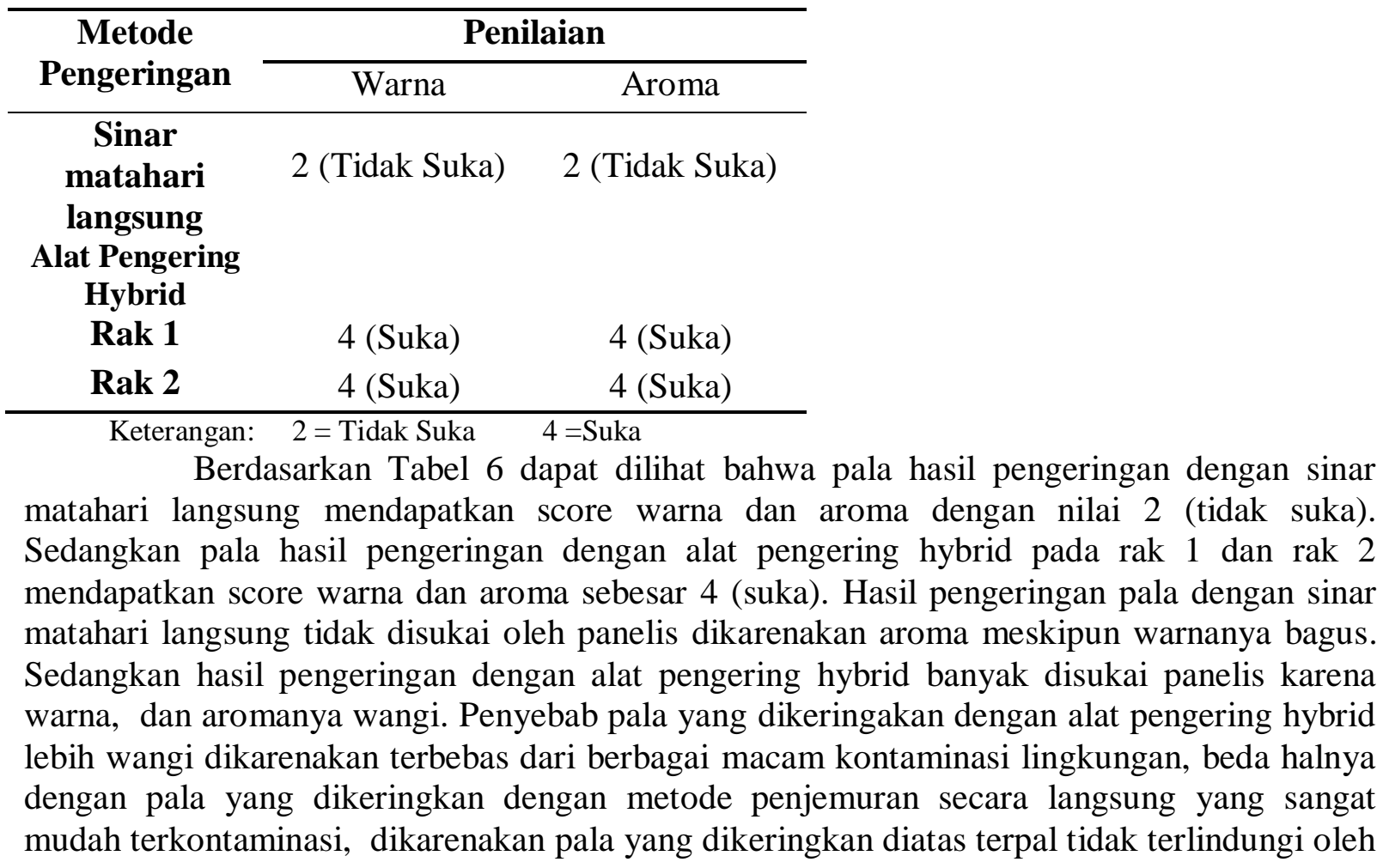


apapun dan dibiarkan begitu saja jadi sangat rawan akan kontaminasi lingkungan yang dapat mempengaruhi aroma dan kualitas dari pala itu sendiri. Penilaian organoleptik dilakukan oleh 30 orang panelis yang tidak terlatih terdiri dari berbagai macam kalangan (umum).

\section{KESIMPULAN DAN SARAN}

Adapun kesimpulan dari penelitian ini adalah sebagai berikut :

1. Iradiasi surya berfluktuasi sepanjang waktu karena di pengaruhi oleh posisi matahari dan kecerahan langit dimana iradiasi surya rata-rata tertinggi yang dicapai sebesar $131,61 \mathrm{~W} / \mathrm{m}^{2}$ dan potensi iradiasi surya yang bagus untuk pengeringan terjadi pada pukul 10.00 WIB sampai dengan 15.00 WIB.

2. Rata-rata temperatur dalam ruang pengering lebih tinggi dari temperatur lingkungan, sedangkan RH ruang pengering lebih rendah dari pada RH lingkungan, kondisi ini menunjukkan alat pengering hybrid cocok untuk proses pengeringan.

3. Pala yang dikeringkan dengan alat pengering hybrid lebih cepat mencapai kadar air akhir 10\%, dengan waktu 32 jam atau 1,5 hari (kontinu) dari pada pala yang dikeringkan dengan metode penjemuran matahari dengan media terpal dengan waktu 39 jam atau 4 hari (Intermiten).

4. Pala hasil pengeringan dengan alat lebih disukai oleh panelis dari segi warna dan Saran aroma dibandingkan pala yang dikeringkan dengan metode penjemuran matahari.

Adapun saran yang dapat diberikan pada penelitian ini adalah perlu modifikasi alat pengering dengan penambahan pipa penukar panas.

\section{DAFTAR PUSTAKA}

Badan Standardisasi Nasional .1993. SNI Biji pala Nomor 01-0006-1993.

Badan Standardisasi Nasional .1993. SNI Fuli Nomor 01-0007-1993.

Kakomole, J.B. 2012. Karakteristik Pengeringan Biji Pala (Myristica Fragrans Houtt) Menggunakan Alat Pengering Energi Surya Tipe Rak. Skripsi Jurusan Teknologi Pertanian Fakultas Pertanian Universitas Sam Ratulangi. Sulawesi Utara.

Rismunandar. 1990. Budidaya dan Tata Niaga Pala. PT. Penebar Swadaya.Jakarta.

Taib, G., Said, G., dan Wiraatmadja, S. 1987. Operasi Pengeringan Pada Pengolahan Hasil Pertanian. Penerbit Mediyatma Sarana Perkasa. Jakarta. 